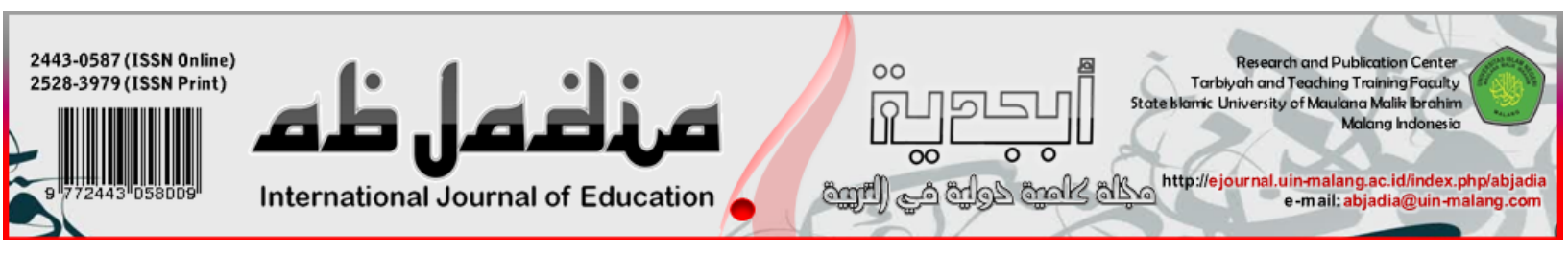

\title{
THE IMPLEMENTATION OF SCIENTIFIC APPROACH ON BIOLOGY LEARNING GRADE $X$ STATE HIGH SCHOOL VIEWED BY TEACHER'S EMPLOYMENT STATUS
}

\author{
Hefi Marrdias Siwi' ${ }^{1}$, Dwi Maihidin Pahlifi ${ }^{2}$ \\ 1,2 Universitas Negeri Yogyakarta, Indonesia
}

Article History:

Received : 2019-11-09

Revised : 2019-12-05

Accepted : 2019-12-11

Published : 2019-12-30

Keywords:

Implementation, Scientific Approach,

Biology Teachers, Biology Learning

$\overline{\text { Correspondence Address: }}$

hefimardias7@gmail.com

dwimaihidinpahlepi@gmail.com

\begin{abstract}
This research aimed to examine the implementation of a scientific approach on biology learning of grade X state senior high school in Wonogiri viewed from teacher's employment status. It is descriptive research using the observation method. The subject involved Biology teachers of grade $X$ and the students of grade $X$ as many as 1 class from each school. Employing a convenience sampling technique, the researchers selected a sample of 6 biology teachers from grade X. The independent variable was the biology teacher's employment status, and the dependent variable was the scientific implementation approach on biology learning. The instrument used in this research was an observation sheet. The acquired data then analyzed descriptively. The research results have indicated that biology teachers' employment status who is a civil servant or non-civil servant has implemented the scientific approach well. The students' involvement and activity were positive during the learning process.
\end{abstract}

\section{C) Introduction}

The scientific approach is the approach used in the learning process of curriculum 2013. This approach invites students directly to find problems on the presented problem formulations and hypotheses, a sense of caring for the environment, and curiosity (Sudirman, 2015). Learning activities in the scientific approach consist of 5M, namely Observing, Asking, Data Collection, Associating, and Communicating. The purpose of the scientific method is to provide understanding to students in knowing, understanding various materials using a scientific approach, that information may come from anywhere, at any time, and not only depend on a teacher (Hosnan, 2016).

The curriculum 2013 simultaneously began to implement in 2014 in all schools at the elementary and secondary education levels. The curriculum 2013 is a competencybased curriculum by strengthening the process of learning and authentic assessment to achieve the competencies. Of course, in making the indicator, the teacher plays an essential role in planning, a method for evaluation.

A success learning will always demand the creativity of the teacher, as well as in the learning process using curriculum 2013, which emphasized on character and 
competence, where the teacher is an essential factor for the success of learning. Teachers are required to create conducive learning and students' curiosity. So, education must be students-oriented. Thus, teachers must change learning methods into student-centered learning (Mulyasa, 2015).

The scientific approach is known through many learning models applied by teachers. The learning model as referred in regulation of Ministry of Education and Culture (Permendikbud) Number 103 of 2014 and Permendikbud Number 22 of 2016 is a learning model highlights the activities and creativity, inspires, fun and initiative, student-centered, authentic, contextual and meaningful to students' daily lives, such as (1) Discovery learning model, (2) Inquiry learning model, (3) Problem Based Learning Model, (4) Project Based Learning Model, and learning model other than lecturing or memorization method (Direktorat Pembinaan SMA, 2017).

The teacher is familiar with the learning model, but, in its implementation, the teacher sometimes is not able to apply the learning model. As stated by the directorate of high school development (2017) that most problems of teachers are, not all teachers understand the learning models. Moreover, the teachers may recognize a particular learning model, and they put them in the lesson plan, but they may not implement it during the learning process. This fact shows that the teacher knows the model but does not understand the chosen learning model.

The teacher has a variety of backgrounds, such as employment status. Staffing status may become a factor influencing teacher performance in learning. In Government Regulation No.38 of 1992 concerning education, personnel explained that the employment status of teachers divided into; permanent teachers, permanent teachers with civil servants (PNS), permanent teachers but non-PNS, and non-permanent teachers (Presiden Republik Indonesia, 1992). Then, teachers may distinguish into teachers with PNS status and non PNS / honorarium status. Between these two teacher employment statuses, there are certainly differences, seen from salary, performance, competence, and other things. Booth, Francesconi \& Franck (2002) states that contract employees also receive wages below the average permanent employee. And this difference affects performance. Research by Wickramasinghe (2011) proved that there are differences in job satisfaction levels based on employment status. Analysis by Burgess (2006: 129) also confirmed that there are differences in the job satisfaction level between permanent employees and contract employees.

The results of the quality assurance of education in Wonogiri Regency conducted by LPMP in Central Java showed that the quality of education at Senior High School in 2016 has not yet reached the National Education Standards (SNP). In the SNP score for the standard process, which related to the learning process, the lowest score is in the planning of the learning process with a score of 3,890 (towards SNP level 3), and this score indicates far from the SNP, namely at a score of $6.66 \leq$ ratings $\leq 7.00$. The learning plan made by the teacher is the beginning and determines the implementation of the 
learning process. By looking at the analysis results conducted by LPMP at Central Java and linking to factors supporting the quality of education, the role of the teacher becomes a problem in the learning process in Wonogiri regency.

\section{[Q] Method}

The particular research was a qualitative descriptive study using survey methods. The research conducted in March to May 2019 in 6 senior high schools in Wonogiri Regency. Sampling was established by convenience sampling because the population was a teacher who was a hypothetical population. The community was all biology teachers at class X of senior high school in Wonogiri Regency. The sample was six biology teacher at class $X$ of senior high school and students of one class $X$ from each of these biology teachers. The instruments were observation sheets to find out the implementation of the learning and questionnaire sheet to find out the background of the teacher.

Data were analyzed descriptively and tabulated into tables and diagrams. The data from observations calculated in numbers, and then analyzed with the following formula:

$$
\mathrm{P}=\frac{f}{N} \times 100 \%
$$

Where:

P: Number/Percentage Obtained

f: Obtained Score

$\mathrm{N}$ : Maximal Score

The interpretation of the obtained scores presented in table 1 (Arikunto, 2011):

\begin{tabular}{cc} 
Table.1 Interpretation of Learning Implementation \\
\hline Score & Interpretation \\
\hline $84 \%-100 \%$ & Excellent \\
$63 \%-83 \%$ & Good \\
$52 \%-62 \%$ & Enough \\
$36 \%-51 \%$ & Poor \\
\hline
\end{tabular}

Student participation analyzed with the following stages:

a. Count the active students during the learning process

b. Percentage of the calculation results

c. Make criteria of the results of the percentage, with the following criteria:

\begin{tabular}{ccc} 
& \multicolumn{2}{c}{ Table 2. Interpretation of Students Participation } \\
\hline Percentage (\%) & Criteria & Interpretation \\
\hline $\mathbf{5 0}-\mathbf{1 0 0}$ & 3 & all-almost of all student has active participation \\
$\mathbf{0}-<\mathbf{5 0}$ & 2 & A small number of student has active participation \\
$\mathbf{0}$ & 1 & None of the students has active participation \\
\hline
\end{tabular}

The differences in implementation between PNS teachers and Non-PNS teachers were analyzed statistically using the t-test. 


\section{Result}

The observation sheet based on the results of preliminary research related to the learning model that most widely used by biology teachers at class $\mathrm{X}$ in all SMA Negeri in Wonogiri regency. Initial investigation showed that of 18 biology teacher at class $\mathrm{X}$ of SMA in Wonogiri regency, nine teachers used Discovery learning, and the rest of teachers use other learning models such Inquiry learning, Problem-based learning, and projectbased learning. Based on this result, the researchers took six samples of teachers who often used the discovery learning model. The results and discussion presented as follows.

Based on observations on biology teacher at class $X$ aimed to determine the implementation of a scientific approach in the process of learning by using the discovery learning model, the results presented in Table 3.

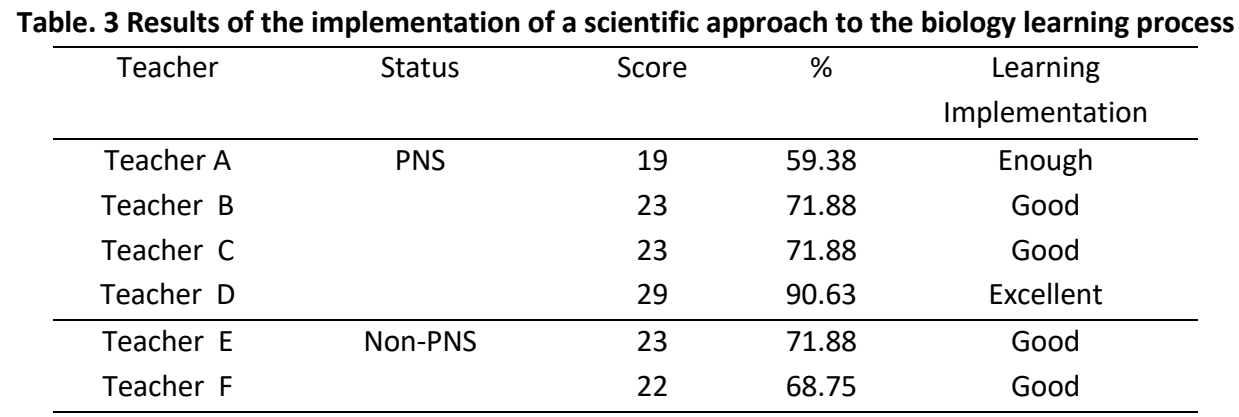

The results then converted into a diagram;

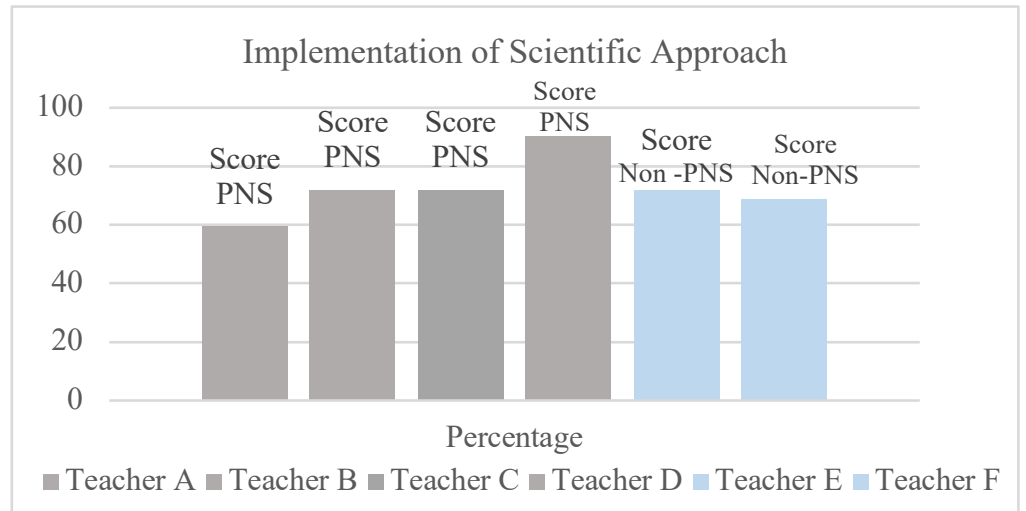

Figure 1 Implementation of Scientific Approach

Based on table 3 and figure 1 showed that six teachers have well-implemented a scientific approach. Teacher D obtained the highest score, which showed the implementation of the scientific method in learning was excellent. Four other teachers $(B$, $\mathrm{C}, \mathrm{E}$, and F) showed that the implementation of the scientific approach in education was unique. And Teacher A obtained scores 19, indicating that the application of the scientific method in learning is enough.

Based on the observation, then the data tested parametrically using a t-test (independent T-test) - the result presented in Table 4.

Table 4. Result of Independent t-test 


\begin{tabular}{ccccccc}
\hline & & \multicolumn{2}{c}{$\begin{array}{c}\text { Levene's Test for Equality } \\
\text { of Variances }\end{array}$} & \multicolumn{3}{c}{ t-test for Equality of Means } \\
\hline \multirow{2}{*}{ Score } & $\mathrm{F}$ & Sig & $\mathrm{t}$ & $\mathrm{df}$ & Sig. (2-tailed) \\
& $\begin{array}{c}\text { Equal } \\
\text { variances } \\
\text { assumed }\end{array}$ & 1.301 & 0.318 & 0.322 & 4 & 0.764 \\
\cline { 2 - 7 } & $\begin{array}{c}\text { Equal } \\
\text { variances not } \\
\text { assumed }\end{array}$ & & 0.471 & 3.329 & 0.667 \\
\hline
\end{tabular}

Table 4 showed the value of sig. ( 2 tailed) was $0.764(>0.05)$. This means that there is no significant difference in the ability to implement scientific approaches in biology learning between teachers with PNS and Non-PNS teachers. The participation of students during the biology learning process presented in table 5.

\begin{tabular}{|c|c|c|c|}
\hline Teacher & $\begin{array}{l}\text { Number of } \\
\text { Students }\end{array}$ & $\begin{array}{c}\text { Percentage } \\
(\%)\end{array}$ & Students Participation \\
\hline Teacher A & 32 & 88 & $\begin{array}{l}\text { All - most of them have active } \\
\text { participation. }\end{array}$ \\
\hline Teacher B & 19 & 85 & $\begin{array}{l}\text { All - most of them have active } \\
\text { participation }\end{array}$ \\
\hline Teacher C & 32 & 80 & $\begin{array}{c}\text { All - most of them have active } \\
\text { participation }\end{array}$ \\
\hline Teacher D & 35 & 91 & $\begin{array}{c}\text { All - most of them have active } \\
\text { participation }\end{array}$ \\
\hline Teacher E & 36 & 77 & $\begin{array}{c}\text { All - most of them have active } \\
\text { participation }\end{array}$ \\
\hline Teacher $\mathbf{F}$ & 36 & 75 & $\begin{array}{c}\text { All - most of them have active } \\
\text { participation }\end{array}$ \\
\hline
\end{tabular}

Based on table 5, all-most of students have active involvement in the learning process of biology. Students who are taught by teacher D showed the highest percentage, while students who are motivated by teacher F showed the lowest rate

\section{¡imi Discussion}

The particular study aimed to find out the implementation of the scientific approach conducted by biology teacher at class $X$ of Senior high school, while the sample of 6 teachers (teachers A, B, C, D, E, and F) was from 6 senior high schools in Wonogiri Regency. The biology teacher will determine the background of employment status. In this study, there were four teachers with PNS status, namely teacher of A, B, C, and D, and two non-PNS teachers, namely teachers $\mathrm{E}$ and F. Teachers. The results showed that the implementation of the scientific approach that performed by teachers with PNS and Non-PNS have well-implemented, with the interpretation of enough to excellent. The explained that the teacher could implement the scientific method in discovery learning in biology learning.

The role of the teacher in the learning process is not natural since the planning of learning to evaluate the results. In doing the plan, of course, many things are considered, such as the selection of learning models because the learning aimed at the students can understand the material, and the learning process can run well and fun. By considering 
the participation of students during the learning process (table 5) showed that both teachers, PNS and Non-PNS, can perform their roles as teachers. Metzler (Thomas, 2007) also states that in discovery learning, the primary function of the teacher is to stimulate thinking and lead the development of students' psychomotor domains. The question will be the most prominent discourse. The teacher acts as a facilitator of student learning that encourages students by lead students to ask questions. Here, this action will encourage students' exploration and creativity.

The active participation of students in the learning process undoubtedly expected to achieve the goal and learning objectives. During the observation process, the students' involvement seen in many aspects of learning. The active roles that are seen are students answering questions raised by the teacher, students observing outside the classroom, conducting discussions during observations, conducting studies in the school, presenting the results of the data, asking the teacher and arguing during conversations with fellow friends in a group, looking for data information through sources such as books and internet, and conducting question and answer on presentations. Mulyasa (2014) stated that the implementation of scientific methods in forming KI-KD requires the active participation of students because they are the center of goals and the formation of competencies. The student must involve targeted questions and answers and seek solutions to various learning problems.

Based on the results of the statistical test (T-test), found out that there is no significant difference in the ability of scientific approach implementation between PNS and Non-PNS teachers. These results, when compared with the results of observation (table 2), the results are following the interpretation of the implementation of 6 teachers that all of them have a suitable category. The absence of this difference is possibly caused by many things, for example, the work ethic. Sari et al. (2013) state that the work ethic comes from the attitude of self-development. Meanwhile, for non-PNS teachers, it may already be insisted on performing the best as an educator. The research also mentioned that teachers have a higher work ethic and are easier to have the best performance in the work environment. When linked to the results of this study, both teachers with PNS and Non-PNS may have a high work ethic.

The welfare of the teacher may be another possibility. Health is related to external factors that affect teacher performance, namely, income. Hargreaves and Flutter (2013) stated that several factors affect teacher status; one of them is the income or salary earned by the teacher. They also mentioned that the level of teacher job satisfaction also depends on the income earned by the teacher. Then, the government today continues to increase the welfare of teachers, both PNS and Non-PNS teachers. Quoted from the website of the Ministry of Education and Culture (2019) states that the Government continues to strive to increase the welfare of educators through the provision of professional teacher allowances. In this case, the government continues to make serious efforts to improve the dignity of teachers, advance the teaching profession, and encourage the improvement of the quality of learning. In 2017, the government, through regional transfers, disbursed 
IDR 55.1 trillion to 1,310.7 million teachers of Regional Civil Servants (PNSD). In 2019, the budget increased to Rp56.9 trillion. While the number of funds transferred by the Government through the central funding mechanism transferred by the Ministry of Education and Culture (Kemendikbud) to the accounts of each non-PNS teacher amounted to IDR 4.8 trillion in 2017, increasing to IDR 5.7 trillion in 2019. By this increasing may improve better the spirit and performance of teachers, both PNS, and Non-PNS teachers.

The successful implementation of the learning process is not only the responsibility of the teacher but also the involvement of students, school citizens, and the school environment must support the implementation. Moreover, the government also demanded to continue to improve the teacher welfare because of the increasing number of demands for the teachers in the curriculum 2013; the government should also increase the level of protection. Also, we need to consider the learning infrastructure aimed the students are more interested and actively involved in learning. As a result, the achievement of learning objectives in the curriculum 2013 can be achieved with excellent results.

\section{Conclusion}

Based on the results and discussion, concluded that teachers with the status of PNS and non-PNS have a well-implemented scientific approach to the learning process of biology in class $X$. There is no significant difference in the ability to implement a scientific strategy on biology learning of class $X$ in senior high schools in Wonogiri regency between teachers with the status of PNS and non-PNS. The level of student participation shows that all-most of students has actively involved during the learning process.

\section{Bibliography}

Arikunto, S. (2011). Prosedur Penelitian: Suatu Pendekatan Praktik. Jakarta: PT. Rineka Cipta. hal.236

Booth, A, L., Francesconi, M., \& Frank, J. (2002). Temporary jobs: Stepping stones or dead ends?. Economic Journal, Vol.112. pp.189-213

Burgess, J. Conell, J. (2006). Temporary work and human resources management; issues, challenges, and responses. Personnel Review. Vol.35. pp.129-140

Direktorat Pembinaan SMA (2017). Model-model Pembelajaran. Jakarta: Direktorat Jenderal Pendidikan Dasar dan Menengah. Hal.1,10 (2017)

Hargreaves, L., and Flutter, J. (2013). The Status of Teachers and the Teaching Profession: A desk-study for Education International. Unpublished manuscript, Department of Education, University of Cambridge, UK. pp.11

Hosnan, M. (2016). Pendekatan Saintifik dan Kontekstual Dalam Pembelajaran Abad 21: Kunci Sukses Implementasi Kurikulum 2013. Bogor: Ghalia, Indonesia. Hal.39 
Kemendikbud (2019). Pemerintah terus Tingkatkan Kapasitas dan Kesejahteraaan Guru. Dikutip https://www.kemdikbud.go.id/main/blog/2019/03/pemerintah-terus-tingkatkan-kapasitasdan-kesejahteraan-guru.

Lembaga Penjamin Mutu Pendidikan. (2016). Laporan Peta Mutu Pendidikan Kabupaten Wonogiri Provinsi jawa Tengah Berbasis SNP Tahun 2016. Semarang: LPMP Jawa Tengah.

Mulyasa. (2014). Pengembangan dan Implementasi Kurikulum 2013. Bandung: PT Remaja Rosdakarya. Hal.101

Mulyasa. (2015). Guru dalam Implementasi Kurikulum 2013. Bandung: PT Remaja Rosdakarya. Hal.66

Presiden Republik Indonesia. (1992). Peraturan Pemerintah RI No.38, tahun 1992, Tentang Tenaga Kependidikan

Sari, T.E.,Imron, A., \& Setyadin, B. (2013). Perbedaan Tingkat Etos Kerja Antara Guru Tetap dan Guru Tidak Tetap. Manajemen Pendidikan Vol.14, No.24. Hal.175-180

Sudarisman. (2015). Memahami Hakikat dan Karakteristik Pembelajaran Biologi dalam Upaya Menjawab Tantangan Ababd 21 serta Optimalisasi Implementasi Kurikulum 2013. Jurnal Florea Volume 2 No.1. pp.29-35.

Thomas, Glyn. (2007). Skill Instruction in outdoor leadership: A comparison of a direct instruction model and a discovery- learning model. Australian Journal of Outdoor Education, Vol.11 No 2. pp.10-18.

Wickramasinghe Et al. (2011). Differential effects of employment status on work-related outcomes A pilot study of permanent and casual workers in Sri Lanka. Journal of Employee Relation, Vol 33, pp.532-550.

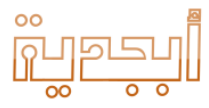

